\title{
ASSET MANAGEMENT OF THE PUBLIC SECTOR IN POLAND
}

\author{
Małgorzata Rymarzak, PhD \\ Faculty of Management \\ University of Gdansk \\ e-mail:mrymarzak@wzr.ug.edu.pl
}

Dariusz Trojanowski, PhD
Faculty of Management
University of Gdansk
e-mail: dtrojanowski@wzr.ug.edu.pl

Abstract

Public sector bodies own diverse, valuable but capital-intensive assets, which require the following of all the changes taking place in their environment and their trends (conducting market analyses), as well as the anticipation of future effects of present-day actions (decisions). It seems, however, that many public bodies/entities make decisions according to current needs, hardly ever conducting market analyses or market valuation of their assets.

Today, both theory and practice offer a variety of methods - instruments supporting the process of decision-making concerning the creation of a rational structure of real property, sources of its financing, evaluation of the effectiveness of using individual fixed assets and their impact on the economic situation of each body/entity.

The purpose of this paper is to present the nature and scale of the problem of asset management, as well as the main elements of the process of the management of real property owned by public entities, based on a case study of the biggest Polish cities.

At first, we will outline the scale of the problem, including the gross value of buildings and structures and capital expenditures of the public sector. Then, we will present the definition of asset management and classification of real property as tools and conditions for effective asset management, as well as the results of empirical research conducted with officials responsible for property management in Poland's six largest cities.

Keywords: asset management, public sector.

\section{JEL Classification: L85.}

Citation: Rymarzak M., Trojanowski D., (2012), "Asset Management of the Public Sector in Poland", Real Estate Management and Valuation, vol. 21, no. 1, pp. 5-13.

DOI: $10.2478 /$ remav-2013-0001.

\section{Introduction}

Public sector bodies own one of the largest real estate resources in Poland. There is a large variety of real assets owned by public entities; they include land occupied by roads and water and sewage infrastructure, wastewater treatment plants, landfills, cemeteries, land for public investment projects and areas for residential and commercial development. On top of this, the assets include school buildings, tenements, business premises, etc.

The possession of such diverse, valuable but capital-intensive property requires that changes in its environment and their trends be followed, and future effects of present-day actions (decisions) be 
anticipated. It seems, however, that many public bodies/entities make decisions according to current needs, hardly ever doing any market analysis or market valuation of their assets.

Today, both theory and practice offer a variety of methods and instruments supporting the process of decision-making concerning the creation of a rational structure of real property, sources of its financing, evaluation of how effectively individual fixed assets are used and their impact on the economic situation of each body/entity.

The purpose of this paper is to show the nature of the asset management of public entities ${ }^{1}$, as well as the scale of the problem and main elements of the process of asset management, based on a case study of the biggest Polish cities.

We have tried to achieve this goal by using both secondary sources (e.g. Polish and foreign books, statistical data on the value, dynamics and structure of fixed assets, and especially real property of the Polish public and private sectors) and primary ones, i.e. the results of empirical research carried out in January and February 2013 by means of direct interviews with officials responsible for real property management in six of the largest Polish cities: Gdańsk, Cracow, Łódź, Poznań, Warsaw and Wrocław.

\section{Public property management: scale of the problem}

In order to operate and achieve its objectives, each entity, whether public or private, must possess certain economic resources. All of these resources, at the entity's disposal and necessary for current and further development activities, are defined as assets. Their size and structure are largely dependent on the scale of and type of activities assumed by a given entity, which contributes to their diversity in terms of volume and value in its constituent bodies.

The structure of gross value of fixed assets in Poland has not changed much over the last few years. Since 2005, the value of public sector fixed assets has constituted nearly $40 \%$ of total assets. At the end of 2010, the value of public sector buildings and structures was more than PLN 770 billion, which was over $77 \%$ of the total value of fixed assets of the sector in question (Figure 1).

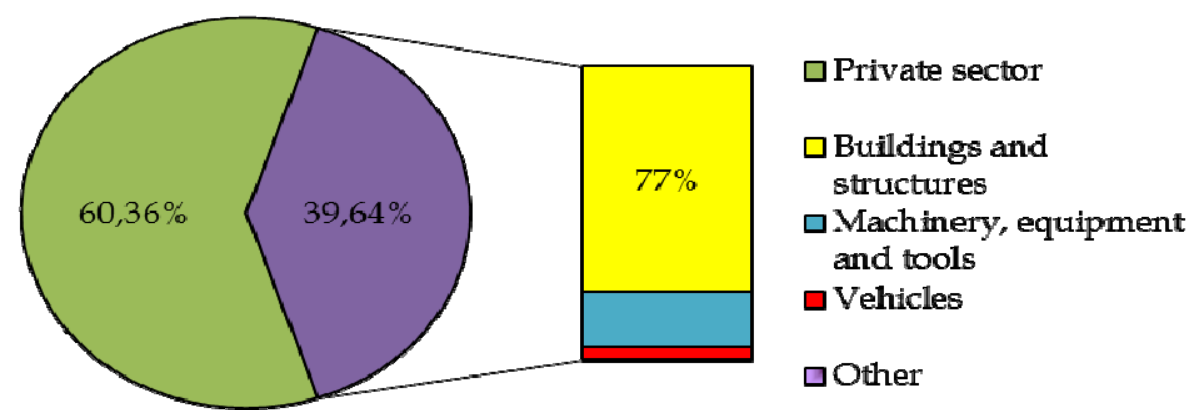

Fig. 1. The structure of the gross value of fixed assets in Poland by sectors, 2010. Source: authors' own elaboration based on: Środki trwałe w gospodarce narodowej w 2011 roku GUS, http://www.stat.gov.pl/gus/5840_806_PLK_HTML.htm, access on 28 Nov. 2012.

In the period of 2003-2010, there was a systematic growth of asset value in the public sector (as compared with the private sector) (Figure 2). The increase in public assets resulted from investment projects carried out in this period, largely funded by EU resources and undertaken irrespective of the prevailing business trends.

The gross value of buildings and structures shown above was the result of systematic capital expenditure. Figure 3 illustrates its level in 2003-2010 and the proportion of total capital expenditure in the GDP.

${ }^{1}$ We use the term "asset" deliberately - it will be explained later on. 


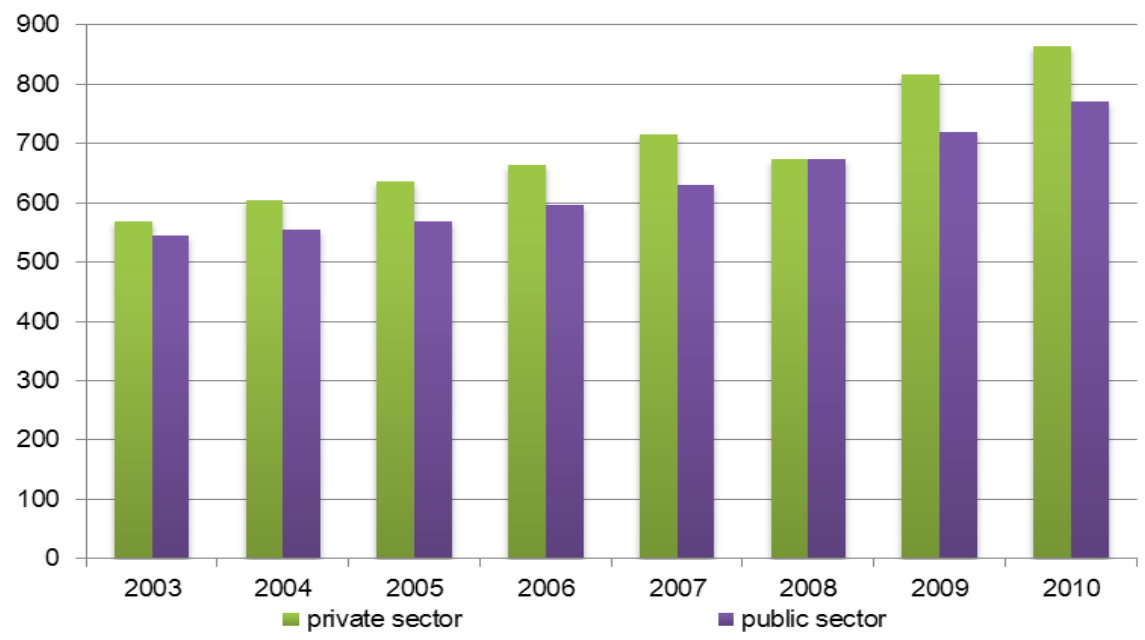

Fig. 2. Gross value of buildings and structures in the public and private sectors in $2003-2010$

(billion PLN). Source: authors' own elaboration based on: Środki trwate w gospodarce narodowej w latach 2003-2011, GUS, http://www.stat.gov.pl/gus/5840_806_PLK_HTML.htm, access on 28 Nov. 2012.

The highest value of public sector capital expenditure in the period in question was in 2010 - when it amounted to over PLN 70 billion, accounting for over $5 \%$ of the GDP.
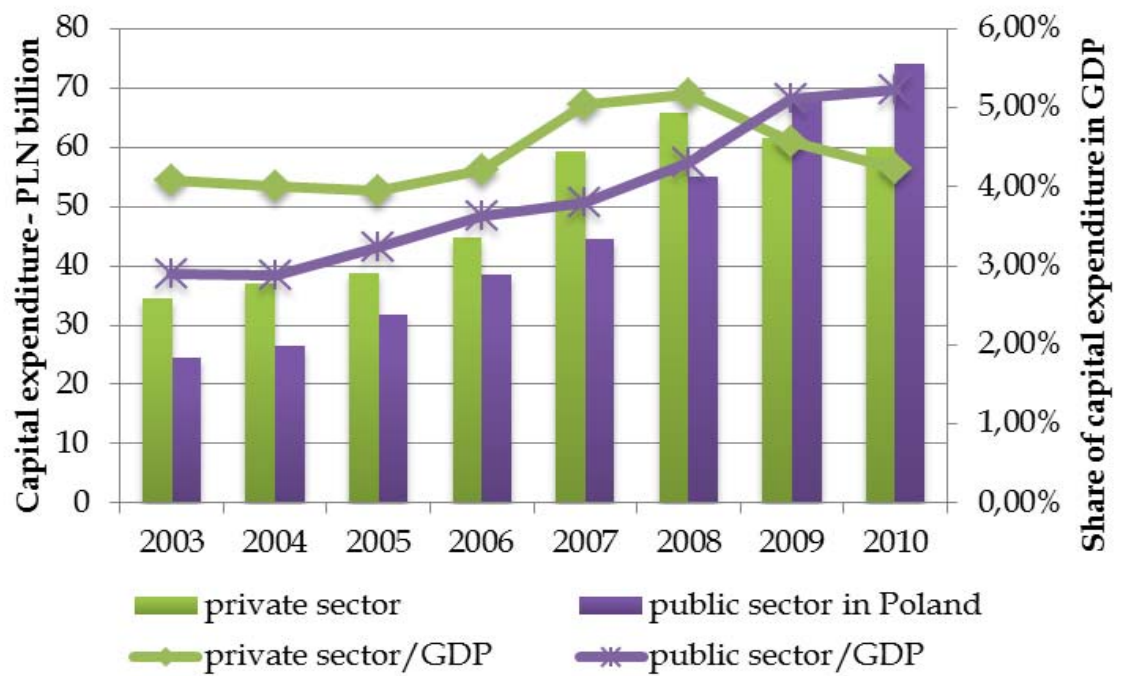

Fig. 3. The level and dynamics of capital expenditure on buildings and structures in Polish private and public sectors in 2003 - 2010 (PLN billion and \%)Source: authors' own elaboration based on:

Środki trwałe $w$ gospodarce narodowej w latach 2003-2011, GUS,

http://www.stat.gov.pl/gus/5840_806_PLK_HTML.htm, access on 28 Nov. 2012.

The possession of such considerable property, its structure and effective use of, which determine the financial and economic position of the entity, are undoubtedly a strategic problem of great importance and, if it is to be managed in the best possible way, those managing it must have an adequate information base.

\section{The concept of asset management}

As compared with the traditional definition of real property management, "asset management" covers a wider range of activities and is not confined to the operational stage, but refers to the whole life cycle of the property (HOWARTH, 2006; PHELPS 2010). Asset management is a process of making decisions and their implementation related to real estate acquisition, use and disposal (KAGANOvA, 
2012).

Moreover, as K. Jones and A. D. White point out, it is a kind of activity which ensures the optimisation of the use of properties owned by an entity, thus enabling it to carry out its business and achieve its long-term objectives (JONES \& WHITE, 2008).

Asset management covers numerous operations and activities performed in a variety of areas, including, e.g., inventory, valuation, portfolio analysis, auditing and reporting (FERNHOLZ \& FERNHOLZ, 2007). This makes it necessary to study the demand for fixed assets by analysing the environment (HAYNES \& NUNNINGTON, 2010) and the strategic goals of the entity (CONWAY, 2006; PARIDA, 2012). Each property should be assessed in terms of its current use versus its best possible use in order to determine its market value (VERMIGLIO, 2011). It should be pointed out here that market value will vary significantly, especially on markets lacking equilibrium between supply and demand.

All these factors must be taken into account when making decisions on: property disposal, change in a building's location or class, new construction or buying a property on the secondary market, lease or sub-lease with changing rent levels.

\section{Real property classification: a tool for effective asset management}

A major prerequisite of rational asset management by public entities is the adoption of a proper classification based on pre-determined criteria. The choice of criteria may vary, yet most typically they result from praxis or the existing regulations.

F. Fernholz and R. M. Fernholz indicate that on the basis of various real property records it is possible to put assets into three main groups: buildings, infrastructure and land. These records usually also contain information on the owner and user of the property, so the latter may also be classified according to the various titles to it (FERNHOLZ \& FERNHOLZ, 2007).

Public property may also vary in terms of its function - it may, on the one hand, be land under roads, water and sewage networks, sewage treatment plants, landfills, cemeteries or land designated for public investment projects, and on the other - land for residential or commercial development. This is complemented by school buildings, tenements as well as commercial premises.

Table 1 below shows the public property classification applied in some of the European countries, according to how the property is used.

Table 1

Examples of public property classification in selected European countries according to its use

\begin{tabular}{|c|c|c|c|c|c|}
\hline Property use & Denmark & Germany & France & Luxemburg & Netherlands \\
\hline Education & $\mathrm{V}$ & $\mathrm{V}$ & $\mathrm{V}$ & $\mathrm{V}$ & $\mathrm{V}$ \\
\hline Sports & V & $\mathrm{V}$ & V & V & V \\
\hline $\begin{array}{l}\text { Administration } \\
\text { buildings }\end{array}$ & V & V & V & V & V \\
\hline Health & V & V & & V & $\mathrm{V}$ \\
\hline Culture & V & V & V & & V \\
\hline Welfare & $\mathrm{V}$ & $\mathrm{V}$ & V & $\mathrm{V}$ & V \\
\hline Other & $\mathrm{V}$ & $\mathrm{V}$ & V & V & V \\
\hline Housing & $\mathrm{V}$ & & $\mathrm{V}$ & $\mathrm{V}$ & \\
\hline Warehousing & $\mathrm{V}$ & & & $\mathrm{V}$ & \\
\hline Libraries & $\mathrm{V}$ & & & & \\
\hline Nurseries & $\mathrm{V}$ & & & & \\
\hline $\begin{array}{l}\text { Commercial } \\
\text { premises }\end{array}$ & & V & & & \\
\hline
\end{tabular}

Source: authors' own elaboration based on: Municipal Real Estate. Comparing Public Real Estate Management in European Cities, Deloitte, December 2011.

The table demonstrates that real property used for the same purpose can be grouped differently in various countries. In Luxemburg, for instance, buildings having welfare and cultural functions do not form separate categories, but are put in the "Other" group. Real property used for housing is in France understood to mean employee accommodation. In Germany, properties classified as having welfare function mean youth residential establishments, while in France they signify healthcare and welfare 
buildings.

An entirely different classification of public property is used in Italy, naming infrastructure, green areas, public administration buildings, environmental projects as well as schools, cultural and transport facilities.

From the asset management perspective, it is the division based on what purpose the property is meant to serve that is most crucial in trying to ensure its best possible use and lower costs. Accordingly, P. Dent suggests the following classification of real property (DENT, 1997):

1) direct service property - the property used to affect the basic tasks of public entities (the town hall, schools, healthcare facilities, etc.);

2) tenanted property -the property that public entities can lease, let or grant usufruct rights to maximise the profit derived from it as well as the property used to satisfy other needs, e.g., economic, welfare, etc.;

3) vacant property - the property that is either redundant or has been purchased in view of future goals (e.g., the widening of a motorway, public urban space, etc.).

A different classification developed by M. A. Utter (1989) and later adapted by O. Kaganova (2012) provides for the division of public property, according to its function, into three major groups:

1) mandatory - the property used to perform the basic functions of public entities;

2) discretional - the property owing to which public, political and other initiatives can be supported;

3) surplus or revenue-generating - the property that is in neither of the categories above and can generate one-off profit from its sale or regular profit in rent.

A similar approach to the Polish public property sector was suggested in 2008 by K. Dziworska and D. Trojanowski, in whose opinion municipal property should be divided into (DZIWORSKA \& TROJANOWSKI, 2008):

1) functional (statutory) property - used by public sector entities to perform their basic tasks;

2) instrumental property of:

- socio-economic nature, provisionally used to support socio-economic initiatives (e.g., premises meant for commercial lease temporarily used on preferential terms);

- spatial development nature - a reserve for specific future goals;

3) income-generating property, including:

- rent-generating assets, which bring periodical income in rent;

- disposable assets - bringing one-off income, e.g., upon their sale.

The suggested classification may be a starting point for the development of an asset management strategy of public entities, as it differentiates between property which is indispensable for the functioning of the municipality and the performance of its statutory tasks, property designed to support both short- and long-term development objectives of the municipality, and property which the municipality may dispose of.

For each of the above, different management methods will be needed, as seen through various financial goals.

Functional (statutory) property is usually a fixed and loss-making resource of public sector bodies and, as such, it should be evaluated and managed from the operational perspective - the goal it is designed to satisfy (LU, 2011). This is by no means a simple task, as changes in the surrounding environment have to be taken into account and the property held should be adjusted to the existing and changing needs, both in terms of quality and quantity.

The management of this type of property should focus on the effective use of the asset and on keeping its operating expenses reasonably low (KAGANOVA \& NAYYAR-STONE \& PETERSON, 2000), if possible, making the asset self-supporting. Properties of this kind, by nature, do not generate a profit for public entities, yet the opportunity cost of not using them in the most profitable way is an important issue here. For this reason, decisions regarding the use of each property should follow a cost-benefit analysis and public administration buildings should not be located in the commercially most attractive areas.

The management of instrumental property will primarily be based on the criteria of grant amount, the running costs of the property and the revenue it may, at certain times, generate. The subject of consideration may in this case be the ways of reducing grants - both directly and indirectly allocated in support of the property, its operating costs as well as vacant space that can be leased until the land 
is developed for its ultimate use.

Public bodies may also own income-generating property that is not needed for their primary operations and which is meant to be a source of revenue to fund their statutory tasks. When looking at what type of economic benefit the public bodies can derive, real property falls into two groups: rentgenerating assets and disposable assets.

The portfolio of rent-generating assets covers properties that generate periodical income in the form of rent, other charges or the share of the owner in profits from the business operations, such as:

1) commercially rented space;

2) commercially rented buildings;

3) land under lease.

The other group is disposable assets, meaning property which is not and will not be used for the performance of the statutory tasks of the public entity and can, therefore, be sold. Assets of this type may include:

1) undeveloped land of various use;

2) developed land with buildings to be demolished;

3) developed land with buildings that may further be used.

A number of issues invariably have to be considered when deciding to dispose of an asset, like the property market trend (upward/downward); the management of this type of property also carries questions, such as: Is the present situation in the market in favour of the sale or against it? At what price can the property be sold?

If the property can neither be sold nor leased, it is important that the running costs and other liabilities it generates are kept as low as possible.

Summing up the above, we have to say that the problem of asset management has been well studied in both Polish and foreign writing (BRZESKI \& JUREK \& SZCZAWIŃSKA, 2005; DZIWORSKA \& TROJANOWSKI, 2008; KOTLIŃSKA, 2009; KOKOT \& GNAT, 2010). Property market practitioners have also been providing asset management guidance to local government bodies during dedicated consultancy projects held in Poland. ${ }^{2}$ It is, therefore, interesting to see if local authorities have attempted to apply the asset management concept to property management, or if the problem has been disregarded.

\section{Elements of the public sector asset management process - survey results}

An empirical study, the results of which are presented in Table 2, was conducted in January and February 2013 and constituted a survey of Poland's six largest cities. The survey covered cities with a population exceeding 450 thousand, as of 30 June, 2012 (LUDNOŚć. STAN..., 2012). The choice of the cities for the survey was deliberate, based on the assumption that it is the largest cities that are in the forefront of asset management implementation and dissemination of the best practices.

The research project was undertaken under the assumption that decisions made in the field of asset management by local government bodies should:

1) be consistent with the strategic objectives of the relevant body as well as the purpose for which the given asset is used, the extent to which it is used, its physical condition and market value;

2) be preceded by an analysis of the real property market;

3) be based on an analysis of various options and the choice of the one that is most economically sound;

4) be made by or in conjunction with a team/unit with adequate expertise and tools, the latter including an IT application or system (SIMONS, 1992; MUNICIPAL REAL ESTATE..., 2011; ABDULLAH \& RAZAK \& PAKIR, 2011);

5) account for costs, revenues and risks throughout the life of the asset (HASTINGS, 2010).

Table 2 below shows the findings of the interviews. For the purpose of various schedules and analyses, most of the cities covered by our study classify the property in their control according to two basic criteria: its use and form of tenure. Classification from the asset management point of view is done only in Poznań. It may, therefore, be concluded that the asset management concept as described in the literature of the subject and based on the classification of property into 3 basic groups, i.e., functional, instrumental and income-generating properties, is recognised in only one of the studied cities. Cities do not have information regarding the market value of their assets. Property valuation is

2 This includes, inter alia, the EBRD funded Programme of Developing Municipal Creditworthiness, run between 2000 and 2007. 
performed only when required by property management legislation (e.g., when the property is to be sold). City officials claimed there was no need for such valuations and that they are rather costly. What is used in various schedules is the book value of the asset. The asset management concept, which the authors of the present article refer to, is based, among others, on the issue of the so-called opportunity cost, which in turn is based on the market value resulting from the best possible way in which the property can be used. The use of a property for a specific purpose by the local government results in the "freezing" of capital that the property represents. In certain cases, it is possible to dispose of the property or obtain periodical income from it. The knowledge of opportunity cost (value) of individual property items is, therefore, necessary if a decision is to be made and can be used for the relocation of the various functions which local authorities have to perform (KAGANOVA, 2012; GELTNER \& MiLLER, 2007; GRUBišIĆ \& NuŠINOvić \& ROJE, 2009).

Table 2

Elements of asset management in selected Polish cities

\begin{tabular}{|c|c|c|c|c|c|c|}
\hline $\begin{array}{c}\text { Elements } \\
\text { of asset } \\
\text { management } \\
\text { process }\end{array}$ & Gdańsk & Cracow & Łódź & Poznań & Warsaw & Wrocław \\
\hline $\begin{array}{c}\text { Is the } \\
\text { property } \\
\text { classified } \\
\text { from an asset } \\
\text { management } \\
\text { perspective? }\end{array}$ & No & No & No & $\begin{array}{l}\text { Yes, classification } \\
\text { has been done }\end{array}$ & No & No \\
\hline $\begin{array}{l}\text { Is the market } \\
\text { value of each } \\
\text { property } \\
\text { known? Are } \\
\text { the changes } \\
\text { analysed? }\end{array}$ & $\begin{array}{c}\text { No such } \\
\text { knowledge }\end{array}$ & $\begin{array}{l}\text { No such } \\
\text { knowledge }\end{array}$ & $\begin{array}{l}\text { No such } \\
\text { knowledge }\end{array}$ & $\begin{array}{c}\text { No such } \\
\text { knowledge }\end{array}$ & $\begin{array}{c}\text { No such } \\
\text { knowledge }\end{array}$ & $\begin{array}{l}\text { No such } \\
\text { knowledge }\end{array}$ \\
\hline $\begin{array}{l}\text { Are regular } \\
\text { property } \\
\text { market } \\
\text { surveys } \\
\text { conducted for } \\
\text { the purpose } \\
\text { of asset } \\
\text { management? }\end{array}$ & $\begin{array}{l}\text { No regular } \\
\text { surveys }\end{array}$ & $\begin{array}{l}\text { No regular } \\
\text { surveys }\end{array}$ & $\begin{array}{c}\text { Yes, } \\
\text { in-house } \\
\text { surveys }\end{array}$ & $\begin{array}{l}\text { No regular } \\
\text { surveys }\end{array}$ & $\begin{array}{c}\text { Yes, } \\
\text { in-house } \\
\text { surveys }\end{array}$ & $\begin{array}{c}\text { Yes, } \\
\text { in-house } \\
\text { surveys }\end{array}$ \\
\hline $\begin{array}{c}\text { Are } \\
\text { individual } \\
\text { properties } \\
\text { and decisions } \\
\text { in their } \\
\text { respect } \\
\text { analysed? }\end{array}$ & $\begin{array}{c}\text { Yes, } \\
\text { in selected } \\
\text { areas } \\
\text { by different } \\
\text { units }\end{array}$ & $\begin{array}{c}\text { Yes, } \\
\text { in selected } \\
\text { areas } \\
\text { by different } \\
\text { units }\end{array}$ & $\begin{array}{c}\text { Yes, } \\
\text { in selected } \\
\text { areas } \\
\text { by different } \\
\text { units }\end{array}$ & $\begin{array}{c}\text { Yes, } \\
\text { in selected } \\
\text { areas } \\
\text { by different } \\
\text { units }\end{array}$ & $\begin{array}{c}\text { Yes, } \\
\text { in selected } \\
\text { areas } \\
\text { by different } \\
\text { units }\end{array}$ & $\begin{array}{c}\text { Yes, } \\
\text { in selected } \\
\text { areas } \\
\text { by different } \\
\text { units }\end{array}$ \\
\hline $\begin{array}{l}\text { Is there an } \\
\text { asset } \\
\text { management } \\
\text { supporting } \\
\text { IT application } \\
\text { in your } \\
\text { organisation? }\end{array}$ & No & $\begin{array}{l}\text { No, } \\
\text { but work is } \\
\text { underway to } \\
\text { develop one }\end{array}$ & $\begin{array}{l}\text { No, } \\
\text { but work is } \\
\text { underway to } \\
\text { develop one }\end{array}$ & $\begin{array}{l}\text { No, } \\
\text { but work is } \\
\text { underway to } \\
\text { develop one }\end{array}$ & No & $\begin{array}{l}\text { No, } \\
\text { but work is } \\
\text { underway to } \\
\text { develop one }\end{array}$ \\
\hline $\begin{array}{c}\text { Is there a } \\
\text { team/unit in } \\
\text { your } \\
\text { organisation } \\
\text { responsible } \\
\text { for asset } \\
\text { management? }\end{array}$ & No & No & No & $\begin{array}{l}\text { No, but it is going } \\
\text { to be the } \\
\text { responsibility of } \\
\text { the Property } \\
\text { Management } \\
\text { Department }\end{array}$ & No & No \\
\hline
\end{tabular}

Source: authors' own

Regular property market surveys are conducted in three of the six cities. The people interviewed, however, pointed out that this was done by various municipal bodies, with their respective needs in mind. Officials conduct such surveys mostly by themselves, using transactions in municipal property 
as the basic source of information. In all the cities, however, decisions concerning real property are analysed, with the scope of the study varying considerably - quite often it is simply to answer the question of whether it should be sold or leased. In all of the cities it was pointed out that the analyses were done by those units within the organisation which were the actual users of the asset. There are no dedicated teams within the municipalities involved in strategic decision-making concerning real property. This may cause the need to hire asset management experts by individual municipal bodies, or the decisions taken may not prove to be as effective as they should be.

Knowledge of the asset portfolio is essential for the asset management process (PROPERTY ASSET..., 2010). This should be broad and result from the audits performed. A possible tool for data collection and generation as well as for the analysis of the available information (e.g., to make comparisons) may be an IT application. None of the cities in the survey had an application that would make it possible to obtain comprehensive information on local government property. What is used by officials is the cadastral resources or databases prepared in-house when needed by individual units within the municipality. Interestingly enough, awareness of the problem seems to exist in four of the cities, where work is being done on asset management systems. While the systems that are planned (e.g., "Skarb" application or Informatyczny System Gospodarowania Nieruchomościami) vary in terms of their functionalities, the system to be implemented at the property management unit of the Poznan City Hall is capable of providing practically all the information about each of the properties (ranging from its area to the cost and revenue it generates). A system of this kind, as a tool supporting the strategic management team, enables decision-makers to make informed choices based on relevant analyses.

\section{Conclusion}

The authors of the present article hold the opinion that their survey concerns an important problem, although little studied in Poland. The management of publicly-controlled real property is a difficult, multidirectional area of strategic importance. This is mostly due to:

1) the volume and the special nature of the properties and the qualitative and quantitative changes they undergo;

2) the complexity of financial phenomena, resulting from the great capital intensity of real property and the variety of methods and sources of financing it;

3) the nature of the costs related to the current use of the assets and their proper maintenance as well as the outlays that have to be made in various investment projects.

Hence, it is necessary to seek efficient methods of managing this complex area which would impact not only on the operations of the relevant municipal units, but also on their financial result.

The survey reveals that none of the cities has fully introduced the asset management concept, yet most of them are aware of the problem, which may possibly be resolved through the implementation of IT real property systems.

Nevertheless, caution must be exercised in evaluating the survey results (even though interviews were conducted with officials in charge of municipal property management). There are two reasons to be cautious: firstly, the reliability of the information provided cannot be adequately verified, and secondly, there is no certainty whether the information and opinions obtained in this way are unbiased and present a full picture.

The authors realise that the study presented here merely highlights the issues mentioned in it, while the results of the survey are but an attempt to identify the elements of the public entity asset management process. It is our hope, however, that the results presented here, based on a review of the relevant literature and the survey conducted, will contribute to a better understanding of the public sector asset management process, while this paper ushers further studies (like a comparison between cities in Poland and elsewhere in Europe) as well as more in-depth research. This seems relevant, as we are familiar with the progress made in this respect in cities smaller than those dealt with in the present paper. In Katowice, for instance, a new unit has been established within the municipality (Wydziat Gospodarowania Mieniem - Asset Management Department), whose tasks are largely consistent with the scope of asset management.

\section{References}

Abdullah S., RaZAK A. A., PAKIR A. H. K., 2011, The characteristics of real estate assets management practice in the Malaysian federal government, Journal of Corporate Real Estate, vol. 13, issue 1. 
BRZESKI W. J., JUREK K., SZCZAWIŃSKA E., 2005, Zarządzanie mieniem komunalnym w miastach polskich, Świat Nieruchomości, No 52-53.

CONWAY F., 2006, Federal Asset Management in Australia, in: Managing Government Property Assets, KaganOva O., MCKellar J. (EDITOR), The Urban Institute Press, Washington.

DENT P., 1997, Managing public sector property assets: the valuation issue, Property Management, vol. 15, no 4.

DZIWORSKA K., TROJANOWSKI D., 2008, Podstawy strategii zarządzania nieruchomościami komunalnymi, in: Inwestycje i nieruchomości wybrane problemy, GOLNAU W. (EDITOR), Fundacja Rozwoju Uniwersytetu Gdańskiego, Sopot.

Fernholz F., Fernholz R. M., 2007, A Toolkit for Municipal Asset Management, Duke University, March.

GRUBišić M., NuŠINOVIĆ M., Roje G., 2009, Towards Efficient Public Sector Asset Management, Financial Theory and Practice 33 (3).

HASTINGS N.A.J., 2010, Physical Asset Management, Springer, London.

HAYNES B. P., NUNNINGTON N., 2010, Corporate real estate asset management. Strategy and implementation, EG Books, Oxford.

HOWARTH A., 2006, Improving asset management in government departments, A report on improving the capability and capacity of managing property assets in central civil government for the office of government commerce, March.

Jones K., White A. D., 2008, RICS Public Sector. Asset Management Guidelines. A guide to best practice, RICS, January.

KAGANOVA O., 2012, Guidebook on real property asset management for local governments, Urban Institute Center on International Development and Governance, IDG Asset Management Toolkit, no 1, February.

Kaganova O., Nayyar-Stone R., Peterson G., 2000, Municipal Real Property Asset Management, An Application of Private Sector Practices, in: Land And Real Estate, Background Series 12, World Bank.

KOKOT S., GNAT S., 2010, Problem efektywności gospodarki nieruchomościami gmin, Studia i Materiały Towarzystwa Naukowego Nieruchomości, vol. 18, no. 2.

KOTLIŃSKA J., 2009, Finansowe aspekty gospodarki nieruchomościami komunalnymi w Polsce, Wydawnictwo UE w Poznaniu, Poznań.

LU Y., 2011, Public Asset Management: Empirical evidence from the state governments in the United States, Florida Atlantic University, Florida, May.

Ludność. Stan i struktura w przekroju terytorialnym. Stan w dniu 30.06.2012, GUS, WARSAW.

Municipal real estate. Comparing public real estate management in European cities (2011), Deloitte, December.

PARIDA A., 2012, Asset performance Assessment, in: Asset management. The state of the art in Europe forma a life cycle perspective, LEI T., HERDER P., WIJNIA Y. (EDITOR), Springer, London.

PHELPS A., 2010, Rationale, practice and outcomes in municipal property asset management, Journal of Corporate Real Estate, vol. 12 issue 3.

Property asset management. Capability assessment model (PAMCAM), 2010, The Office of Government Commerce, London.

SIMONS R. A., 1992, Public Real Estate Management - Adapting Corporate Practice to public sector: The experience in Cleveland, Ohio, The Journal of Real Estate Research, vol. 8, no. 4.

UTTER M.A., 1989, Public Asset Management, Economic Development Commentary.

VERMiglio C., 2011, Public property management in Italian municipalities: framework, current issues and viable solutions, Property Management, vol. 29, issue 5. 